\title{
Lorenzo Gallo*
}

\section{Neotypification of Sedum ochroleucum Chaix (Crassulaceae)}

\begin{abstract}
No original materials (herbarium specimens or drawings) connected with the protologue of Sedum ochroleucum Chaix (Crassulaceae) are to be found; thus the name has been neotypified, selecting a specimen collected by the author in the type locality at Rabou, near Gap (France).
\end{abstract}

Keywords: Dominique Villars, Sedum anopetalum, series Rupestria, Gap, France.

Riassunto - Neotipificazione di Sedum ochroleucum Chaix (Crassulaceae).

Il mancato ritrovamento di materiali originali (exsiccata o illustrazioni) collegabili al protologo di Sedum ochroleucum Chaix (Crassulaceae), ha reso inevitabile la neotipificazione del nome medesimo. A questo scopo l'autore ha effettuato una raccolta di esemplari nei pressi di Rabou (Gap, Francia), ritenuta località tipo della specie.

Parole chiave: Dominique Villars, Sedum anopetalum, serie Rupestria, Gap, Francia.

\section{Introduction and historical background}

The species known as Sedum ochroleucum Chaix $(=S$. anopetalum DC., $\equiv$ Petrosedum anopetalum (DC.) Grulich) was not discovered by Linnaeus, perhaps because of its restricted distribution in the northern Mediterranean Basin. Also Miller (1768), Haller (1768), Lamarck (1778) and Allioni (1785, 1789) don't found it. It was the French priest Dominique Chaix (1730-1799) who discovered it in the neighbourhood of Gap (France); Chaix published this name in Plantae Vapincenses $(1785)^{1}$, distinguishing it from other similar taxa such as $S$. reflexum L. and $S$. rupestre L. ${ }^{2}$

The name $S$. ochroleucum is currently accepted by Webb (1993), Jalas et al. (1999) and 't Hart \& Bleij (2003) whereas Greuter et al. (1986) prefer S. anopetalum. Many French botanists in the past called it $S$. anopetalum (Candolle,

\footnotetext{
* Strada Val San Martino sup. 194, 10131 Torino, Italy; e-mail: lorenzogallo1959@hotmail.it

${ }^{1}$ This work has been subsequently reprinted in Villars's Histoire des plantes de Dauphiné (1786) (cf. Perret \& Burdet, 1981)

${ }^{2}$ Sedum ochroleucum (mihi): foliis oblongis compressis septifariam imbricatis, petalis albidis erectis: Bauxii in collibus (3).
} 
1815; Rouy et al., 1901; Coste, 1903; Bonnier, 1921; Fournier, 1961), in order to avoid the "confusing" S. ochroleucum (see Discussion and conclusions). Its distribution was displayed, with some mistakes, especially for Italy, by 't Hart (2003).

In this series of Sedum (Rupestria Berger), many names have already been typified ('t Hart, 1978; Heath, 1992; 't Hart \& Jarvis, 1993; Gallo, 2008; Gallo \& Jarvis, 2009; Gallo, 2012) but not yet S. ochroleucum. Research by the author has highlighted interesting morphological variability among populations of this taxon, closely correlated with its distribution; typification of the name $S$. ochroleucum, here proposed, is the first step toward a better taxonomic treatment of this rather polymorphic taxon.

\section{The priest Dominique Chaix and his herbarium}

Dominique Chaix carried out his field research in France, in the neighbourhood of Gap (Hautes-Alpes) (Dayrat, 2003) and collected S. ochroleucum at "Bauxii in collibus", that is the mountain near Les Baux, a small village to the North-West of Gap, where he lived and cared for his own personal botanical garden (Garraud, pers. com.).

After his death, Chaix's herbarium (almost 3000 exsiccata) was purchased by Lapeyrouse in 1800 (Timbal-Lagrave, 1856) and then acquired by the Museum of Gap (today Conservatoire Botanique National Alpin) where today, however, it cannot be found. However, Chaix's herbarium is incomplete, at least from the middle of the nineteenth century, according to Timbal-Lagrave (1856). At the Conservatoire only a small herbarium of Chaix is preserved, possibly collected for didactic purposes, but no exsiccata of the genus Sedum could be traced (Garraud pers. com.).

Chaix was a friend and co-worker of Dominique Villars for many years (Poncet, 2001) and many plants collected by the priest of Gap are included in Villars' herbarium, today preserved at GRM (Faure, 2006); here, too, no exsiccata of S. ochroleucum are traceable (see Poncet, 1999).

So, during this research, no suitable original material (herbarium specimens or drawings) or exsiccata collected by Chaix belonging to $S$. ochroleucum has been found.

\section{Typification}

The lack of original material makes neotypification of this name unavoidable (Art. 9.7, I.C.B.N., Melbourne, 2012). Historical research was undertaken to determine the type locality, which is very probably Crête du Devès de Rabou (Gap, France), a mountain near the village of Les Baux where Chaix made frequent excursions (Garraud, pers. com.). In field exploration carried out in June 2010, a large population of $S$. ochroleucum was discovered, together with $S$. rupestre L., and the rather rare hybrid $S$. xlorenzoi 't Hart. Here the neotype of S. ochroleucum was collected; it is morphologically consistent with the protologue, especially for the petals white with green stripes and erect; these characteristics distinguish it from the other two taxa detected in the same area, which have yellowish and spreading petals. 
Sedum ochroleucum Chaix, Pl. Vapinc.: 21 (1785). $\equiv$ Sedum anopetalum DC. var. ochroleucum (Chaix) Posp. Fl. Oesterr. Küstenl., 2 (1): 223 (1899). $\equiv$ S. nicaeense All. var. ochroleucum (Chaix) Fröd., Acta Horti Gothob., 7: 4 (1932) $\equiv S$. rupestre L. subsp. ochroleucum (Chaix) Hegi \& Schmid in Hegi, Ill. Fl. Mitt.-Eur., 4 (2): 541 (1922) $\equiv S$. rupestre L. var. ochroleucum (Chaix) Fiori p.p. (excl. S. montanum Perr. \& Song.) Nuov. Fl. Italia, 1: 721 (1924). - Neotype (designated here): France. Crête du Devès de Rabou (La Roche des Arnauds, Hautes-Alpes), 1400 m., brushwood under the top of the cliff, among the rocks. 7 Jun 2010. L. Gallo \& L. Garraud GL-7060 (G00367611, G) (Figg. 1, 2).

\section{Discussion and conclusions}

The series Rupestria was raised to the genus level (Petrosedum Grulich) in the 1984 and recent molecular studies (Mort et al., 2001) confirm the soundness of splitting the polyphyletic genus Sedum into many small new genera, series Rupestria included. However, this split is not yet recognised formally (cf. 't Hart \& Bleij, 2003; Thiede \& Eggli, 2007) and we prefer to maintain the genus Sedum as a whole.

The species indicated by Chaix was subsequently interpreted wrongly by Villars (1789) as pointed out by Grenier (1865) and Burnat (1906). D. Villars indeed (1789: 680) confused $S$. ochroleucum with $S$. rupestre ([...] les pétales blanchâtres, pointu, ne sont jamais ouverts horizontalement, mais élevés [...]) while with the name $S$. ochroleucum he was clearly identifying $S$. sediforme Jacq. ([...] feuilles ... ovales ... fort épaisses ... pétales ... blancs, obtus, planes \& carinès [...]). Most likely this mistake underlay the opinion of some early French authors (Candolle, 1815; Rouy et al., 1901; Coste, 1903; Bonnier, 1921; Fournier, 1961) who used the name published by de Candolle in the 1815 ( $S$. anopetalum), thus avoiding the "confusing" S. ochroleucum. Conversely, the name given by Chaix is correct from nomenclatural point of view, and it has priority over others names published for this taxon.

This species has two chromosome numbers $(2 n=34,68)$, clearly a diploid and a tetraploid cytotype; these are sympatric but often occur at different altitudes in the same area. Further, the cytotypes are not correlated with any morphological variation found in natural populations of $S$. ochroleucum ('t Hart, 1978). Field and herbarium study has, however, confirmed a trend already observed by 't Hart (1978): from west moving eastwards, the plants are taller and the flowers larger.

Lastly, $S$. ochroleucum hybridises with other taxa of the same series ('t Hart, 1978 ) and a new hybrid between this species and S. montanum Song. \& Perr. (= $S$. xpascalianum Gallo) was recently discovered in the French Alps by the author (Gallo, 2012).

Villars (1789) also describes $S$. aristatum, which, on the basis of the protologue and iconography (Tab. XLV), is very close to $S$. ochroleucum but its distinctive petal morphology still requires proper evaluation. 't Hart (1978) however, consider $S$. aristatum such as synonym of $S$. sediforme.

\section{Acknowledgements}

I am indebted to Luc Garraud (CBNA, Gap-Charance, France) for his invaluable help in finding the type locality of $S$. ochroleucum and for information on Chaix and his herbarium. I am also grateful to Laurent Gautier (curator of the herbarium CJB, Genève) for providing the image of the type and to the referees whose comments improved this paper. 


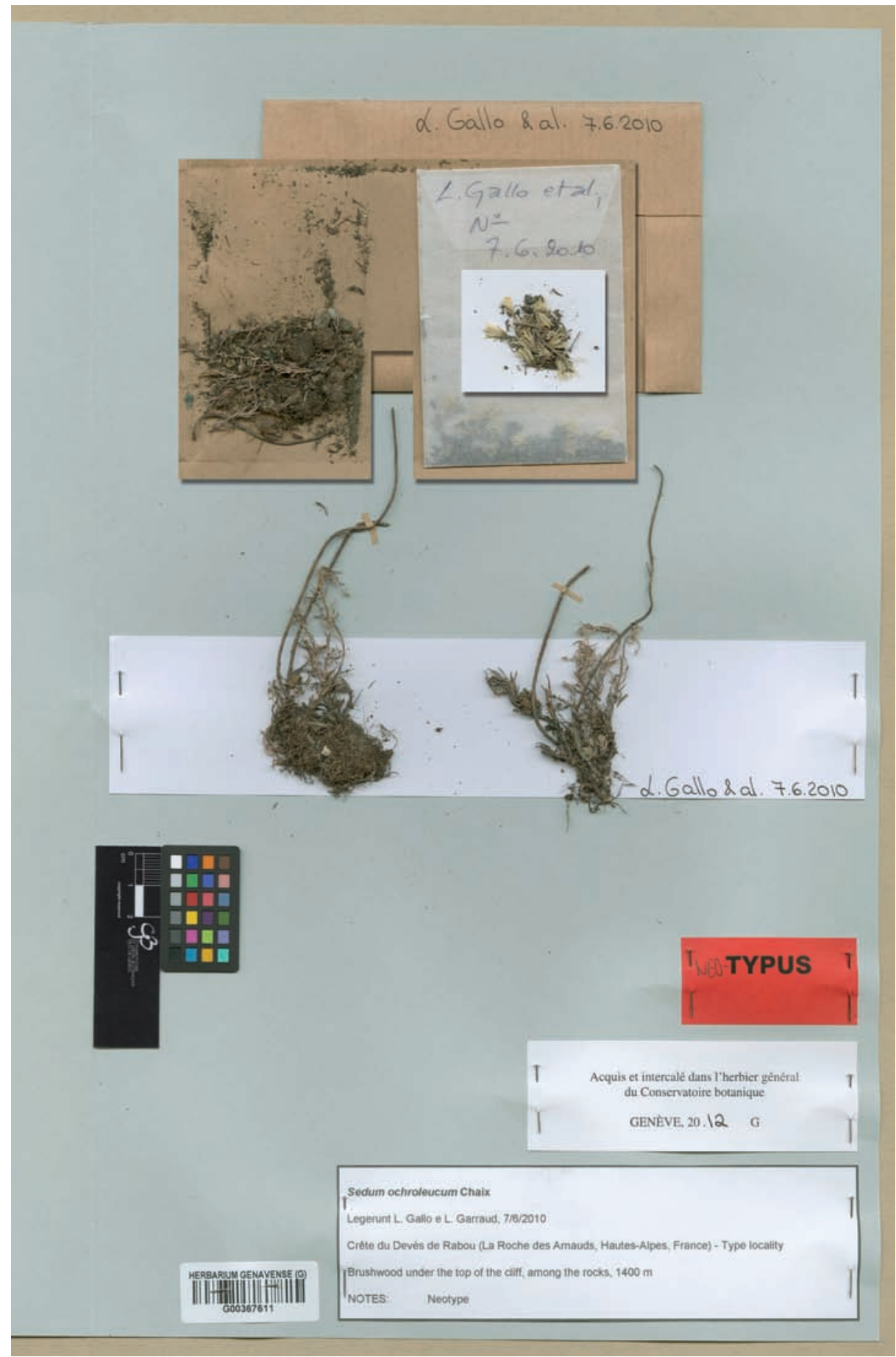

Fig. 1 - Neotype of Sedum ochrolencum Chaix [L. Gallo \& L. Garraud GL-7060, G]. / Neotipo di Sedum ochroleucum Chaix [L. Gallo \& L. Garraud GL-7060, G]. 


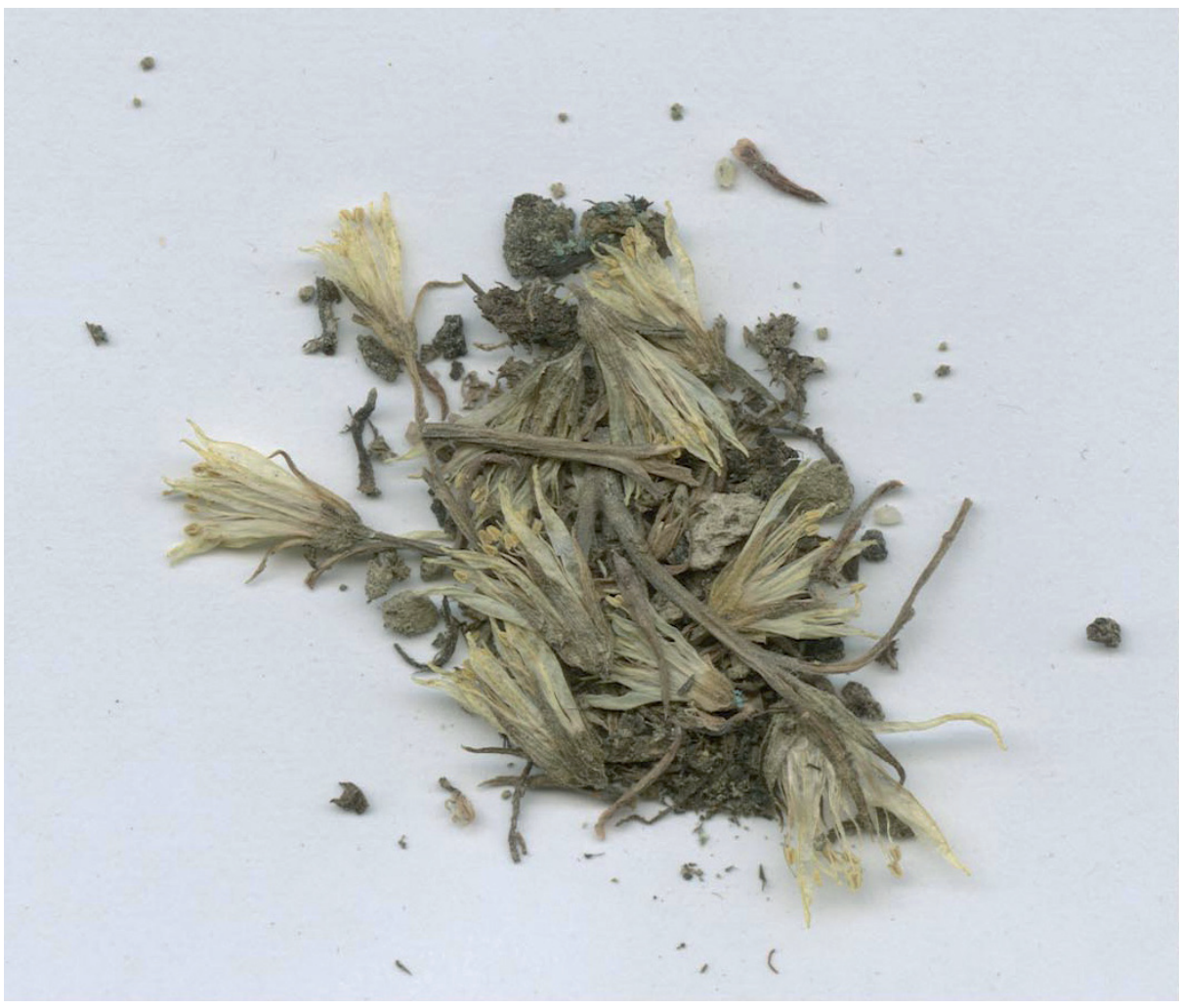

Fig. 2 - Close-up of the flowers. / Ingrandimento dei fiori.

\section{References}

Allioni C., 1785 - Flora Pedemontana. Briolus, Augustae Taurinorum.

Allioni C., 1789 - Auctarium Flora Pedemontana. Briolus, Turin.

Bonnier G. E. M., 1921 - Flore Complète Illustrée en Couleurs de France, Suisse et Belgique. 4. Orlhac, Paris.

Burnat E., 1906 - Flore del Alpes maritimes. 4. H. Georg, Genève, Basel, Lyon.

Candolle A.-P. de, 1815 - Flore Française. $3^{\text {e }}$ ed., 4. Desray, Paris.

Chaix D., 1785 - Plantae Vapincenses. S.l.

Coste H., 1903 - Flore descriptive et illustré de la France. Klincksieck, Paris, 2.

Dayrat B., 2003 - Les botanistes et la flore de France. Trois siècles de découvertes. Muséum National d'Histoire Naturelle, Paris.

Faure A., 2006 - Herbiers de la Région Rhône-Alpes. $2^{\mathrm{e}}$ partie: Catalogue. J. bot. Ville Lyon, Lyon.

Fournier P., 1961 - Quatre Flores de France. $3^{\text {e }}$ ed. Le Chevalier, Paris.

Gallo L., 2008 - Taxonomic notes on some species of Sedum ser. Rupestria Berger (Crassulaceae) and typification of their names. Webbia, Firenze, 63 (2): 169173.

Gallo L., 2012 - Natural hybrids in Sedum series Rupestria Berger (Crassulaceae): a review of the taxonomy and nomenclature. Forum Geobotanicum, 6: 1-13. 
Gallo L. \& Jarvis C. E., 2009 - (1881) Proposal to conserve the name Sedum rupestre (Crassulaceae) with a conserved type. Taxon, Bratislava, 58 (1): $307-$ 308.

Grenier M. C., 1865 - Flore de la châine jurassique. Savy, Paris.

Greuter W., Burdet H. M. \& Long G. (eds.), 1986 - Med-Checkl. 3. Conservatoire et Jardin Botaniques de la Ville de Genève, Genève, 79.

Grulich V., 1984 - Generic division of Sedoideae in Europe and the adjacent regions. Preslia, Praga, 56: 29-45.

Haller A. von, 1768 - Historia Stirpium Indigenarum Helvetiae Inchoata. Soc. Typ. Berne, Berne.

Heath P. V., 1992 - The type of Sedum rupestre Linnè. Calyx, Sutton under Whitestone Cliffe, 2 (2): 82.

Jalas J., Suominen J., Lampinen R. \& Kurtto A., 1999 - Atlas Florae Europaeae. Distribution of vascular plants in Europe. Resedaceae to Platanaceae. Crassulaceae. Cambridge University Press, Helsinki, 12: 40-127.

Lamarck J.-B., 1778 - Flore française. Imprimerie Royale, Paris.

Miller P., 1768 - The Gardeners Dictionary. $8^{\text {th }}$ ed. Miller, London.

Mort M. et al., 2001 - Phylogenetic relationship and evolution of Crassulaceae inferred from matK sequence data. Am. J. Bot., Lancaster, 88 (1): 76-91.

Perret P. \& Burdet H. M. - 1981. Les "Plantae Vapincenses" de Dominique Chaix et les travaux floristiques de Dominque Villars en Dauphiné. Candollea, Genève, 36: 400-408.

Poncet V., 1999 - L'Herbier Dominique Villars (1745-1814). Ed. Museum Hist. nat. Ville Grenoble. Grenoble.

Poncet V., 2001 - Dominque Villars: presentation de son herbier et de ses relations transalpines. Museologia scientifica, Firenze, 16 (1999-2): 159-181.

Rouy G., Foucaud J. \& Camus E. G., 1901 - Flore de France. Asnières, Seine, 7.

't Hart H., 1978 - Biosystematic studies in the Acre-group and the series Rupestria Berger of the genus Sedum L. (Crassulaceae). Thesis. Utrecht.

't Hart H., 2003 - Sedums of Europe. Stonecrops and Wallpeppers. Eggli U. (ed.). A. A. Balkema, Lisse.

't Hart H. \& Bleij B., 2003 - Sedum. In: Illustrated Handbook of Succulent Plants. Crassulaceae. Eggli U. (ed.). Springer-Verlag, Berlin.

't Hart H. \& Jarvis C. E., 1993 - Typification of Linnaeus's names for European species of Sedum subgen. Sedum (Crassulaceae). Taxon, Bratislava, 42: 399410.

Thiede J \& Eggli U., 2007 - Crassulaceae. In: The Families and genera of Vascular Plants. Kubitzki (ed.). Springer, Berlin, Heidelberg, 9: 83-118.

Timbal-Lagrave E., 1856 - Observations critiques et synonymiques sur l'herbier de l'Abbé Chaix. Milhes et Gimet, Toulouse.

Villars D., 1786 - Histoire des plantes du Dauphiné. Tome I. De l'Imprimerie D'Allier, Grenoble.

Villars D., 1789 - Histoire des plantes du Dauphiné. Tome III. De l'Imprimerie D'Allier, Grenoble.

Webb D. A. (ed.), 1993 - Crassulaceae. In: Flora Europaea. Psilotaceae to Platanaceae. Tutin T. G. et al. (eds.). $2^{\text {nd }}$ ed. Cambridge Univ. Press, Cambridge, 1: 422-437. 


\section{Specimina visa selecta}

France. Hautes-Alpes: H. tes Alpes: Devèz de Rabou lisière ouest. 7.1908, L. Girod. Herb. L. Girod (G) (sub S. anopetalum). H. tes Alpes: Gap a Charance. 7.1908, L. Girod Herb. L. Girod (G) (sub S. anopetalum). H. tes Alpes: Devèz de Rabou lisière ouest. 7.1908, L. Girod Herb. L. Girod (G) (sub S. anopetalum). H. tes Alpes: Gap au montant de Bayard a Glaise. 10.7.1902, L. Girod Herb. L. Girod (G) (sub S. anopetalum). H. tes Alpes: Devèz de Rabou lisière ouest. 7.1908, L. Girod Herb. L. Girod (G) (sub S. anopetalum). H. tes Alpes: Gap a Charance. 7.96, L. Girod (G) (sub S. anopetalum). H. tes Alpes: La Freyssinouse. 7.1907, L. Girod Herb. L. Girod (G) (sub S. rupestre var.). H. tes Alpes: Mt. Seuse près Gap. 7.1908, L. Girod (G) (sub S. anopetalum). Sommet de prairie du col de Glaise, pres Gap (Hautes-Alpes) a $2000 \mathrm{~m}$ d'altitude. 9.1860, E. de Valon Fl. Exs. de C. Billot (GAP). Mt. Charance en tête des Devès Hautes-Alpes. 12.8.1866, Burle, herb. Burle (GAP) (sub S. anopetalum). Sigoyer près Gap Hautes-Alpes. 28.6.1868, Burle, herb. Burle (GAP). Col de Glain [Glaise ?] près Gap. 7.1869, s.c. (GAP). Mt. Seuse près Gap Hautes-Alpes. 9.1865, Burle, herb. Burle (GAP). Mt. Seuse près Gap Haute-Alpes. 9.1865, Burle, herb. Burle (GAP). M.gne de Seuse près Gap. 9.1863, Burle (GAP). Corniche di Mt. Seuse près Gap H.tes-Alpes. 9.1863, Burle (GAP) (sub S. verlotii). Sigoyer au ..... [?] Seuse. S.d. s.c. (GAP) (sub S. anopetalum). Hautes-Alpes M. gne de Charance sur Gap. 21.7.1864, Burle. Ex herb. Burle (GAP). Mt. Charance en tête du Devès Haut-Alpes. 12.8.1866, Burle. Ex herb. Burle (GAP). M. gne de Seuse près Gap. 9.1863, Burle (GAP) (sub S. verlotii). Combe-Noire de Menteyer. 28.6.1865, Gariod (GAP) (sub S. verlotii).

Collection numbers (live plants in the author's collection)

France. Hautes-Alpes: Le Baux (La Roche des Arnauds). Rocky grazing with Lavandula angustifolia e Berberis vulgaris. 1123 m, S-E. Gallo L. GL-6624. Gap, Crête du Devès de Rabou (La Roche des Arnauds). Grazing. 1400 m. 7.6.2010, Gallo L. e Garraud L., GL-7060 (Neotype). Gap, Crête du Devès de Rabou (La Roche des Arnauds). Grazing near the road, under the wood. 1200 m. 7.6/.010, Gallo L. e Garraud L., GL-7065. Gap, Crête du Devès de Rrabou (La Roche des Arnauds). Grazing near the road, under the wood. 1200 m. 7.6.2010, Gallo L. $e$ Garraud L., GL-7067. Gap, Crête du Devès de Rabou (La Roche des Arnauds). Ridge. 1500 m. 7.6.2010, Gallo L. e Garraud L., GL-7046. Gap, Crête du Devès de Rabou (La Roche des Arnauds). Ridge. 1500 m. 7.6.2010, Gallo L. e Garraud L., GL-7047. Gap, Crête du Devès de Rabou (La Roche des Arnauds). Grazing. 1400 m. 7.6.2010, Gallo L. e Garraud L., GL-7057. Gap, Crête du Devès de Rabou (La Roche des Arnauds). Grazing near the road, under the wood. 1200 m. 7.6.2010, Gallo L. e Garraud L., GL-7064. Gap, Crête du Devès de Rabou (La Roche des Arnauds). Grazing. 1400 m. 7.6.2010, Gallo L. e Garraud L., GL-7062. Gap, Crête du Devès de Rabou (La Roche des Arnauds). Brushwood under the ridge. 1400 m. 7.6.2010, Gallo L. e Garraud L., GL-7052. Gap, Crête du Devès de Rabou (La Roche des Arnauds). Ridge. 1500 m. 7.6.2010, Gallo L. e Garraud L. GL-7041. Gap, Crête du Devès de Rabou (La Roche des Arnauds). Grazing. 1400 m. 7.6.2010, Gallo L. e Garraud L., GL-7063. Clamensane, Montagne de Reynier, near the "'Passage de Palabiouse". Grazing on the top of the ridge among the rocks. $1450 \mathrm{~m} .23 .09 .2010$, Gallo L., Garraud L. e Van Es J., GL-7272. Clamensane - Montagne de Reynier, under the ridge, side of Reynier, rocky grazing. 1400 m, E. 23.09.2010, Gallo L., 
Garraud L. e Van Es J., GL-7274. Clamensane - Montagne de Reynier, under the ridge, side of Reynier, rocky grazing. 1400 m, E. 23.09.2010, Gallo L., Garraud L. e Van Es J., GL-7275. Clamensane - Montagne de Reynier, under the ridge side of Reynier, rocky grazing. 1400 m, E. 0267978/4909585. 23.09.2010, Gallo L., Garraud L. e Van Es J., GL-7276. Clamensane - Montagne de Reynier, under the ridge side of Reynier, rocky grazing. 1400 m., E. 23.09.2010, Gallo L., Garraud L. e Van Es J., GL-7277.

Ricevuto: 26 novembre 2012

Approvato: 7 gennaio 2013 